\title{
BCR/ABL, IKZF deletions and FLT3-ITD as the targets for relapsed/refractory B-cell acute lymphoblastic leukemia treatment: Blinatu- momab combined with Tyrosine kinase inhibitors and ATRA
}

\begin{abstract}
Andrey N. Sokolov ${ }^{1}$, Elena N. Parovichnikova ${ }^{1}$, Vera V. Troitskaya ${ }^{1}$, Larisa A. Kuzmina ${ }^{1}$, Irina V. Galtseva ${ }^{1}$, Sergei M. Kulikov ${ }^{1}$, Sergey N. Bondarenko ${ }^{2}$, Irina A. Lukyanova ${ }^{1}$, Tatiana I. Lobanova ${ }^{1}$, Ekaterina I. Usikova ${ }^{1}$, Ksenia I. Zarubina ${ }^{1}$, Olga A. Gavrilina ${ }^{1}$, Julia O. Davidova ${ }^{1}$, Nikolai M. Kapranov ${ }^{1}$, Valeriy G. Savchenko ${ }^{1}$

${ }^{1}$ National Research Center for Hematology of the Ministry of Healthcare of the Russian Federation, Moscow, Russia

${ }^{2}$ Raisa Gorbacheva Memorial Research Institute of Pediatric Oncology, Hematology and Transplantation, Pavlov University, St. Petersburg, Russia
\end{abstract}

Dr. Andrey N. Sokolov, National Research Center for Hematology, 4A Novyi Zykovskii Lane, 125167, Moscow, Russia
Phone: +7 (495) 6124592

E-mail: sokolov.a@blood.ru

Citation: Sokolov AN, Parovichnikova EN, Troitskaya VV et al. BCR/ABL, IKZF deletions and FLT3-ITD as the targets for relapsed/refractory B-cell acute lymphoblastic leukemia treatment: Blinatumomab combined with Tyrosine kinase inhibitors and ATRA. Cell Ther Transplant 2020; 9(1): 38-46.

\section{Summary}

Bispecific monoclonal antibody blinatumomab is targeting CD19, being applied for treatment of acute lymphoblastic leukemia (ALL). Several additional targets could be used for combined chemo-free treatment with thyrosine kinase inhibitors: BCR-ABL, FLT3 and IKZF1 deletions are amongst them. In the following study, we aimed to assess toxicity and clinical effectiveness of the combination of blinatumomab and several thyrosine kinase inhibitors.

\section{Patients and methods}

From October 2015 to October 2018, we treated 11 relapsed/refractory (R/R) ALL patients (pts). The blinatumomab treatment consisted of 4-5 cycles with 2-week intervals $(28 \mathrm{mcg} /$ day by continuous infusion during 28 days per cycle with $9 \mathrm{mcg} /$ day during the first week of the first cycle). Seven BCR-ABL-positive and 2 IKZF1-deleted pts received initially dasatinib at $140 \mathrm{mg} / \mathrm{day}$, one case, with FLT3-ITD received sorafenib (800 mg/day). One BCR-ABL-positive pt with T315I mutation was administered ponatinib (45 mg/day). Pts with IKZF1 deletions received ATRA ( $45 \mathrm{mg} / \mathrm{m}^{2} /$ day for 4 weeks) of the $1^{\text {st }}$ blinatumomab cycle and during first 2 weeks of subsequent blinatumomab cycles.

\section{Results}

In the patients responding to blinatumomab treatment, we observed a statistically significant increment of absolute values in T-helper $(\mathrm{p}=0.0034)$, T-cytotoxic $(\mathrm{p}<0.0001)$ and NK $(\mathrm{p}=0.0006)$ cell subpopulations in peripheral blood over the entire treatment period. T-regulatory and double-negative T-cells as potentially inhibitors of $\mathrm{T}$ cell response to blinatumomab remained within low values of normal ranges. Hypogammaglobulinemia was observed in 8 of 11 pts. CR was achieved in 10 pts after $1^{\text {st }}$ cycle of blinatumomab, progressive disease was detected in $1 \mathrm{pt}$. Nine cases of complete molecular remissions (MolCR) and one cytogenetic complete remission were achieved in ten CR pts. Nine allo-BMT and one auto-BMT were performed in $10 \mathrm{CR}$ pts. Three CNS relapses after allo-BMT and one molecular relapse after auto-BMT were diagnosed. One pt died from septic shock after allo-BMT. 


\section{Conclusion}

Blinatumomab combined with TKI has high therapeutic potential as induction remission treatment in targeted ALL population without conventional chemotherapy. High rate of potential CNS relapses could be decreased with more intensive intrathecal prophylaxis.

\section{Keywords}

Acute lymphoblastic leukemia, blinatumomab, tyrosine kinase inhibitors.

\section{Introduction}

Bispecific monoclonal antibodies for targeting tumor cells have a long story from 1980's to produce approved drug in 2014 [1-3]. Several trials for relapsed/refractory acute lymphoblastic leukemia (R/R ALL) treatment including ALCANTARA for Philadelphia chromosome-positive (Ph-positive) R/R ALL were performed and showed clinical effectiveness and even an advantage over chemotherapy (TOWER Study) [4-8]. Recently published results on blinatumomab combined with TKI for therapy of $\mathrm{Ph}$-positive R/R ALL characterized this approach to be safe and effective [11]. Combination of Blinatumomab and TKI could elicit lower toxicity and improve primary results in managing heavily pretreated R/R ALL patients. In preclinical studies, retinoids have shown antileukemic activity in IKZF-deleted ALL [12]. We previously reported about effective combination of blinatumomab with tyrosine kinase inhibitors (TKI) for the treatment of Ph-positive and FLT3-ITD R/R ALL and blinatumomab with TKI and all-trans retinoic acid in IKZF-deleted $\mathrm{R} / \mathrm{R}$ ALL patients $[9,10]$. The aim of our study was to present the data on $11 \mathrm{R} / \mathrm{R}$ ALL patients treated with Blinatumomab and TKI+/-ATRA, omitting simultaneous standard chemotherapy.

\section{Patients and methods}

Eleven patients (pts) with R/R ALL were treated with Blinatumomab + TKI/TKI+ATRA at the National Research Center for Hematology, Moscow, Russia, and in Raisa Gorbacheva Memorial Institute of Pediatric Oncology, Hematology and Transplantation, Saint Petersburg, Russia, from October 2015 to October 2018. The study was approved by the Institutional Review Board. The treatment was administered after the patient has signed informed consent. Blinatumomab was provided by Amgen as part of the expanded access program. The treatment consisted of 4-5 cycles of blinatumomab 28 $\mathrm{mcg} /$ day by continuous infusion for 4 weeks each cycle. Over $1^{\text {st }}$ week of $1^{\text {st }}$ cycle, Blinatumomab was administered at the dose of $9 \mathrm{mcg} /$ day. The 2 -week intervals followed between the rounds of blinatumomab treatment. All the patients were administered one of TKIs: 7 Ph-positive and 2 IKZF1-deleted ALL pts were initially treated with dasatinib ( $140 \mathrm{mg} /$ day) per os, 1 FLT3-ITD ALL patient received sorafenib (800 mg/ day) per os, and one Ph-positive ALL patient with a T315I mutation received ponatinib (45 $\mathrm{mg} /$ day). All the TKIs were administered continuously, from the $1^{\text {st }}$ day of starting blinatumomab. All-trans-retinoic acid (ATRA) at a dose of $45 \mathrm{mg} / \mathrm{m}^{2} /$ day was administered per os in the IKZF1-deleted pts during 4 weeks of the $1^{\text {st }}$ blinatumomab cycle, and during first two weeks of subsequent blinatumomab cycles.
Complete remission (CR) was diagnosed if less than $5 \%$ of blasts were present in bone marrow. Cytogenetic remission (CyR) was diagnosed in the absence of BCR-ABL positive nuclei per 200 nuclei by fluorescence in situ hybridization (FISH). Molecular CR (MolCR) was diagnosed if BCR-ABL/ $\mathrm{ABL}$ at a ratio of $<0.01$ was detected in bone marrow samples by RT-qPCR. The CD3+/CD4+/CD8- T-helper, CD3+/ CD4-/CD8+ T-cytotoxic, CD3+/CD4-/CD8- T-Double-negative, CD3+/CD4+/CD25+ T-regulatory, CD3-/CD56+ NK subpopulations were measured in peripheral blood lymphocytes by flow cytometry weekly during blinatumomab treatment in all the pts ( 1 to 16 samples, 4 points per each blinatumomab cycle). Serum immunoglobulins (Ig) G, M and A were measured during each cycle of blinatumomab (a total of 4 sampling points).

The SAS software was used for statistical evaluation using regression analysis. The MIXED SAS procedure was used to perform repeated measures analysis and to estimate parameters of linear regression of average time-dependent trend.

\section{Results}

Median follow-up was 23 months (19 to 36 months). Median age is 32 years ( 24 to 49 years). Eight pts were females and 3, males. 7 pts received 4 cycles; 1 pt, 5 cycles; 2 pts underwent 2 cycles, and 1 pt was subjected to 1 cycle of blinatumomab treatment. Nine patients had febrile reactions during first two weeks at the $1^{\text {st }}$ cycle of blinatumomab. No one cycle of blinatumomab therapy was not interrupted. Neurological toxicity (1-2 grades) was observed in 2 cases manifesting as headaches in 1 patient, and ulnar neuropathy in 1 case. One patient treated with sorafenib has hand-foot skin syndrome. The syndrome completely resolved after 2 weeks interruption of sorafenib treatment.

Pulmonary infiltrates and pleural effusion in one dasatinib-treated case were completely resolved after switching to nilotinib. Diarrhea associated with dasatinib therapy was observed in 3 patients and resolved after its replacement with bosutinib in 2 cases, and with nilotinib in 1 patient. CMV-associated colitis was diagnosed in 2 cases using virus-specific PCR in stool samples. Massive intestinal bleeding and multiple intestinal ulceration were observed in one patient with CMV colitis, as confirmed by colonoscopy. Facial edema and hyperemia were evident in 1 patient upon dasatinib treatment. These symptoms resolved after passage from dasatinib to nilotinib. Greyness of hair was detected in one patient treated with ponatinib. The main clinical characteristics of individual patients and the events are listed in Table 1.

The weekly performed counts of T-cytotoxic, NK, T-helper and T-regulatory cells in peripheral blood were decreased 
Table 1. Basic clinical characteristics of blinatumomab + TKI-treated ALL patients, response to therapy, and adverse effects

\begin{tabular}{|c|c|c|c|c|c|c|c|c|c|c|c|c|}
\hline $\begin{array}{l}\text { Pt } \\
\text { No }\end{array}$ & $\begin{array}{l}\text { Age, } \\
\text { sex }\end{array}$ & $\begin{array}{l}\text { Mol } \\
\text { var }\end{array}$ & $\begin{array}{l}\text { ALL } \\
\text { status }\end{array}$ & $\begin{array}{l}\text { ABL } \\
\text { muta- } \\
\text { tion }\end{array}$ & TKI, ATRA & $\begin{array}{l}\text { Cycles } \\
\text { No }\end{array}$ & $\begin{array}{l}\text { Response to } \\
\text { Blinatumomab } \\
\text { + TKI +/- ATRA }\end{array}$ & BMT & Status & $\begin{array}{l}\text { OS, } \\
\text { months }\end{array}$ & Toxicity & Late events \\
\hline 1 & $\begin{array}{l}42, \\
\text { female }\end{array}$ & $\mathrm{Ph}+$ & $\begin{array}{l}1^{\text {st }} \text { early } \\
\text { relapse }\end{array}$ & & $\begin{array}{l}\text { Dasatinib, } \\
\text { Nilotinib }\end{array}$ & 4 & MolCR & Allo & $\begin{array}{l}\text { Alive in } \\
\text { MolCR }\end{array}$ & 36 & $\begin{array}{l}\text { pulmonary } \\
\text { infiltrates, } \\
\text { pleural } \\
\text { effusion } \\
\text { CMV colitis }\end{array}$ & \\
\hline 2 & $\begin{array}{l}27, \\
\text { male }\end{array}$ & $\mathrm{Ph}+$ & $\begin{array}{l}1^{\text {st }} \text { cyt } \\
\text { rel }\end{array}$ & & Dasatinib & 4 & MolCR & $\begin{array}{l}\text { Allo } \\
\text { haplo }\end{array}$ & $\begin{array}{l}\text { Aliva in } \\
\text { MolCR }\end{array}$ & 32 & & CNS relapse \\
\hline 3 & $\begin{array}{l}24, \\
\text { female }\end{array}$ & $\mathrm{Ph}+$ & $\begin{array}{l}1^{\text {st }} \text { early } \\
\text { relapse }\end{array}$ & T315I & Ponatinib & 2 & MolCR & Allo & $\begin{array}{l}\text { Alive in } \\
\text { MolCR }\end{array}$ & 22 & Grey hair & CNS relapse \\
\hline 4 & $\begin{array}{l}32, \\
\text { male }\end{array}$ & $\mathrm{Ph}+$ & $\begin{array}{l}1^{\text {st }} \text { early } \\
\text { relapse }\end{array}$ & & Dasatinib & 5 & MolCR & $\begin{array}{l}\text { Auto } \\
\text { Allo } \\
\text { haplo }\end{array}$ & $\begin{array}{l}\text { Alive in } \\
\text { MolCR }\end{array}$ & 19 & & $\begin{array}{l}\text { Mol relapse } \\
\text { after Auto } \\
\text { BMT }\end{array}$ \\
\hline 5 & $\begin{array}{l}30, \\
\text { female }\end{array}$ & $\mathrm{Ph}+$ & $\begin{array}{l}1^{\text {st }} \text { early } \\
\text { relapse }\end{array}$ & & Dasatinib & 4 & CyCR & Allo & $\begin{array}{l}\text { Alive in } \\
\text { MolCR }\end{array}$ & 21 & & \\
\hline 6 & $\begin{array}{l}34, \\
\text { female }\end{array}$ & $\mathrm{Ph}+$ & $\begin{array}{l}1^{\text {st }} \text { early } \\
\text { relapse }\end{array}$ & T315I & Dasatinib & 1 & $\begin{array}{l}\text { Progressive } \\
\text { disease }\end{array}$ & Allo & $\begin{array}{l}\text { Alive } \\
\text { in 4th } \\
\text { relapse }\end{array}$ & 27 & & $\begin{array}{l}2^{\text {nd }}, 3^{\text {rd }}, 4^{\text {th }} \\
\text { relapses }\end{array}$ \\
\hline 7 & $\begin{array}{l}25, \\
\text { male }\end{array}$ & $\begin{array}{l}\text { FLT3- } \\
\text { ITD }\end{array}$ & $\begin{array}{l}\text { Primary } \\
\text { refra- } \\
\text { tory }\end{array}$ & & Sorafenib & 4 & MolCR & $\begin{array}{l}\text { Allo } \\
\text { haplo }\end{array}$ & $\begin{array}{l}\text { Alive in } \\
\text { MolCR }\end{array}$ & 19 & $\begin{array}{l}\text { hand-foot } \\
\text { syndrome }\end{array}$ & \\
\hline 8 & $\begin{array}{l}37, \\
\text { female }\end{array}$ & $\mathrm{Ph}+$ & $\begin{array}{l}1^{\text {st }} \text { early } \\
\text { relapse }\end{array}$ & & Dasatinib & 4 & MolCR & Allo & $\begin{array}{l}\text { Alive } \\
\text { in Mol } \\
\text { relapse }\end{array}$ & 22 & $\begin{array}{l}\text { CMV colitis, } \\
\text { intestinal } \\
\text { ulcerations, } \\
\text { in }\end{array}$ & $\begin{array}{l}\text { CNS relapse, } \\
\text { Mol relapse }\end{array}$ \\
\hline 9 & $\begin{array}{l}36, \\
\text { female }\end{array}$ & $\mathrm{Ph}+$ & MRD+ & & $\begin{array}{l}\text { Dasatinib } \\
\text { Bosutinib }\end{array}$ & 4 & MolCR & Allo & $\begin{array}{l}\text { Alive in } \\
\text { MolCR }\end{array}$ & 23 & diarrhea & \\
\hline 10 & $\begin{array}{l}27, \\
\text { female }\end{array}$ & $\begin{array}{l}\text { IKZF1 } \\
\text { del }\end{array}$ & MRD+ & & $\begin{array}{l}\text { Dasatinib } \\
\text { ATRA }\end{array}$ & 2 & MolCR & Auto & $\begin{array}{l}\text { Alive in } \\
\text { MolCR }\end{array}$ & 21 & & \\
\hline 11 & $\begin{array}{l}49, \\
\text { female }\end{array}$ & $\begin{array}{l}\text { IKZFI } \\
\text { del }\end{array}$ & $\begin{array}{l}\text { Primary } \\
\text { refrac- } \\
\text { tory }\end{array}$ & & $\begin{array}{l}\text { Dasatinib } \\
\text { Nilotinib } \\
\text { ATRA }\end{array}$ & 4 & MolCR & Allo & $\begin{array}{l}\text { Death } \\
\text { from } \\
\text { septic } \\
\text { shock }\end{array}$ & 16 & $\begin{array}{l}\text { face edema } \\
\text { and hyper- } \\
\text { emia }\end{array}$ & $\begin{array}{l}\text { Graft failure, } \\
2^{\text {nd }} \text { haploi- } \\
\text { dentical } \\
\text { Allo-BMT } \\
\text { prolonged } \\
\text { neutropenia }\end{array}$ \\
\hline
\end{tabular}

during the $1^{\text {st }}$ blinatumomab cycle. T-cytotoxic and NK cells returned to normal ranges over the $2^{\text {nd }}$ to $4^{\text {th }}$ blinatumomab cycles. T-regulatory cell counts remained decreased or approached low-normal limits at all terms, except of $2^{\text {nd }}$ blinatumomab cycle (Fig. 1).

Regression analysis (the MIXED procedure in SAS system) was performed for each cell subpopulation, in order to detect significant changes of the $\mathrm{T}$ cell subpopulation kinetics (Table 2 and Fig. 2 a-e). As seen in table 2 in T-helper, T-cytotoxic and NK-subpopulations the weekly gaining effect was statistically significant.

Hypogammaglobulinemia during blinatumomab treatment was frequently observed (Fig. 3), and, in eight patients, treatment with intravenous human normal immunoglobulin was used. To check if the IgG, IgA and IgM kinetics were
Table 2. Weekly gaining effect in distinct T-cell subpopulations. Each sampling point was measured once a week (four points per cycle measured weekly) during 4 cycles of blinatumomab

\begin{tabular}{|l|l|l|l|}
\hline T-cell subpopulation & Estimate & $\begin{array}{l}\text { Standard } \\
\text { Error }\end{array}$ & $\operatorname{Pr}>|\mathrm{t}|$ \\
\hline T-helper & 0.01868 & 0.006220 & 0.0034 \\
\hline T-cytotoxic & 0.04245 & 0.008265 & $<.0001$ \\
\hline T-regulatory & 0.000016 & 0.000227 & 0.9454 \\
\hline NK-cells & 0.009474 & 0.002677 & 0.0006 \\
\hline $\begin{array}{l}\text { Double negative } \\
\text { T-cells }\end{array}$ & 0.000953 & 0.001138 & 0.4045 \\
\hline
\end{tabular}




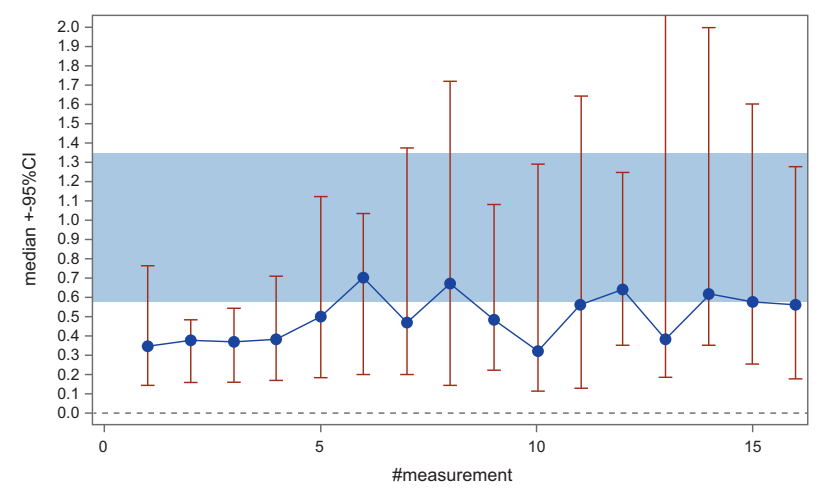

A
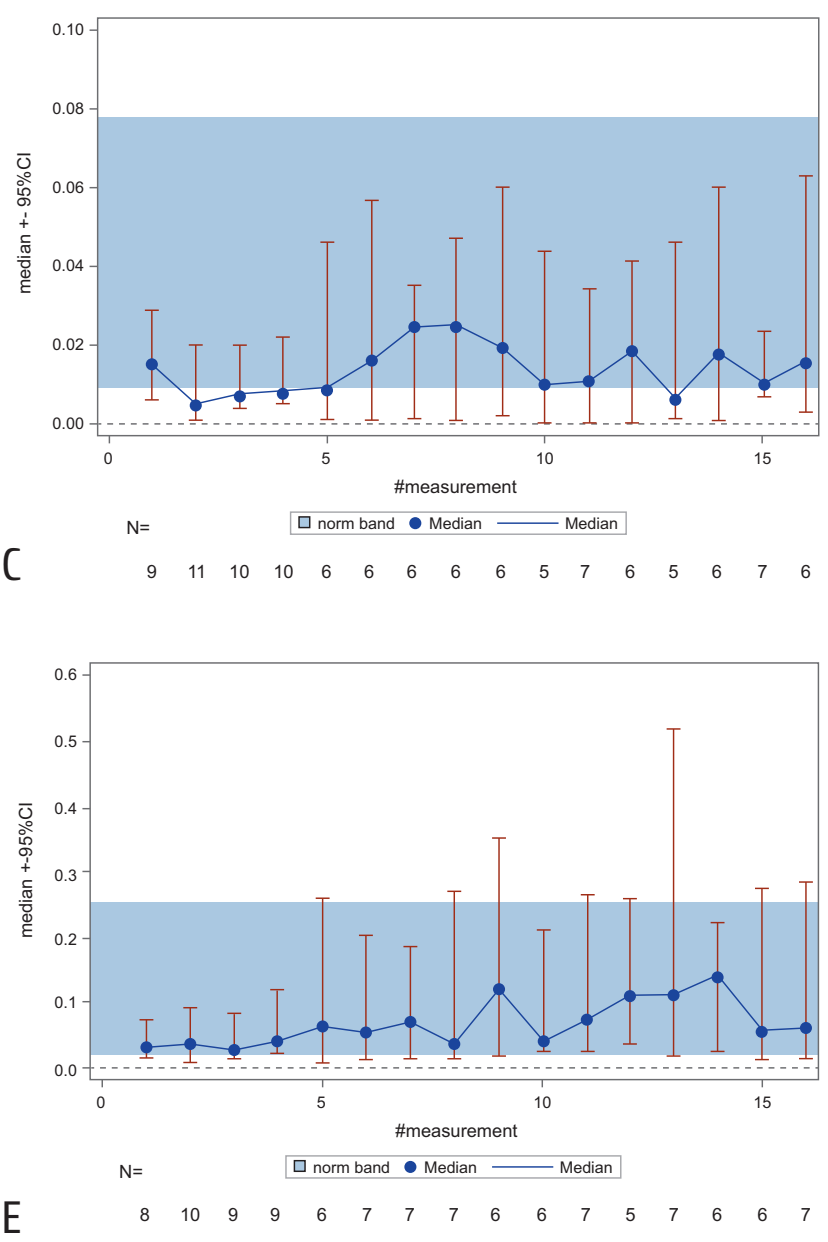

statistically significant, the regression analysis (the MIXED procedure in SAS system) was performed for each Ig (Table 3 and Fig. 4). As seen in Table 3, a gradual decrease in immunoglobulins with each cycle of blinatumomab was statistically significant for IgG, IgA and IgM. Fig. 4 shows the statistically significant effects of Blinatumomab treatment upon $\operatorname{IgG}(\mathrm{p}=0.0446), \operatorname{IgA}(\mathrm{p}<.0001)$, and $\operatorname{IgM}(\mathrm{p}=0.0186)$ (Table 3).

In 10 cases of 11 , complete remission (CR) was achieved after $1^{\text {st }}$ blimatumomab cycle. Progression of the disease was observed in 1 patient during $1^{\text {st }}$ cycle of blinatumom$\mathrm{ab}$ treatment, thus urging us to stop this therapy. Molecular
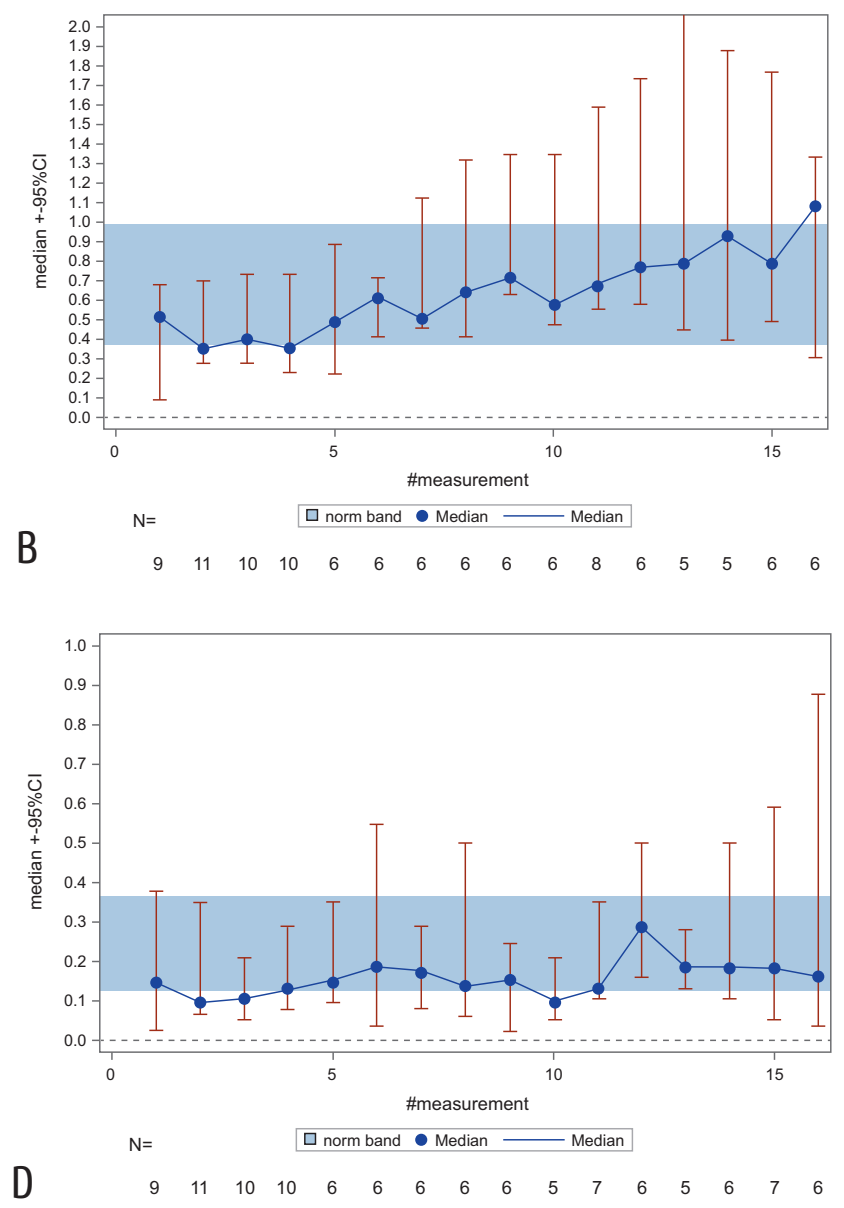

Figure 1. Time kinetics of T-helper cells (A), T cytotoxic cells (B), T-regulatory cells (C), natural killer cells (D), and double-negative cells (E). Median values and $95 \% \mathrm{Cl}$ (confidence interval) are shown for each time point. 16 samples were taken into analyses during 4 cycles of blinatumomab, 4 weekly sampling points for each cycle. Blue band indicates normal ranges for appropriate cell subpopulations. Abscissa, sampling terms, weeks. Ordinate, absolute cell counts in peripheral blood, * ${ }^{*} 10 \%$

Table 3. Weekly decrement in serum IgG, IgA and IgM upon blinatumomab therapy. Each measurement was performed at every treatment cycle (four points weekly over 4 cycles)

\begin{tabular}{|l|l|l|l|}
\hline $\lg$ & Estimate & $\begin{array}{l}\text { Standard } \\
\text { Error }\end{array}$ & $\operatorname{Pr}>|\mathbf{t}|$ \\
\hline $\lg G$ & -5.8542 & 2.7618 & 0.0446 \\
\hline $\lg A$ & -3.6165 & 0.7595 & $<.0001$ \\
\hline $\lg M$ & -18.7529 & 7.4245 & 0.0186 \\
\hline
\end{tabular}




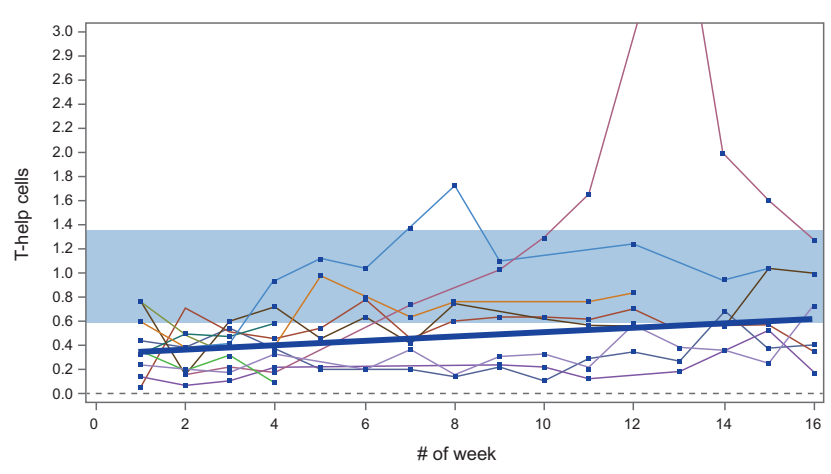

A

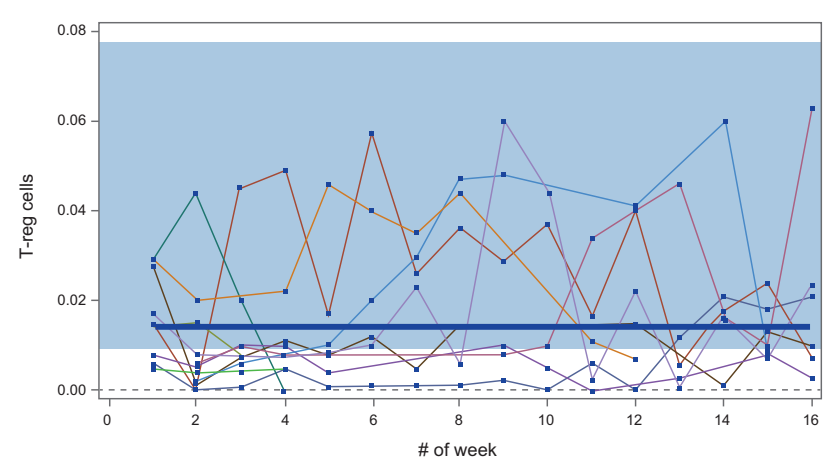

C
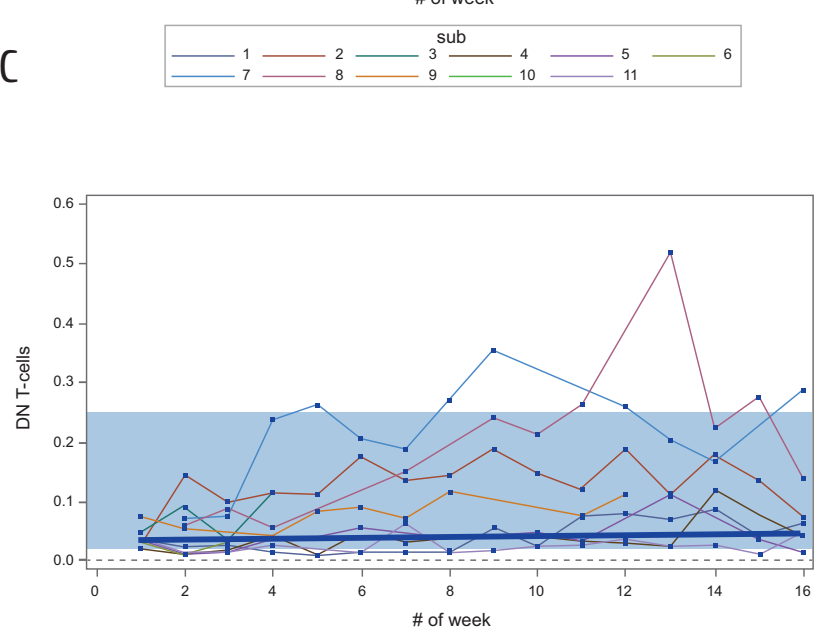

$\mathrm{E}$

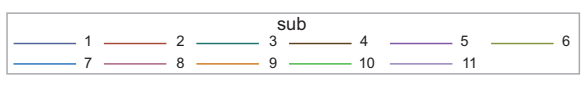

CR (MolCR) was achieved in 9 cases, and cytogenetic CR was detected in 1 patient during consequent blinatumomab cycles. Allogeneic BMT was performed in 9 cases, and auto-BMT, in 1 patient with MolCR. Overt rapid hematological relapse was diagnosed in 1 patient under bosutinib maintenance therapy while waiting for alloBMT. Subsequent MolCR was achieved in the patient with bortezomib-based chemotherapy + dasatinib. One cytogenetic relapse was observed in 1 patient with complete cytogenetic remission before alloBMT. One patient treated with dasatinib as maintenance therapy after auto-BMT had molecular relapse, and second MolCR was achieved after Blinatumomab retreatment + dasatinib + ATRA. Allo-BMT from haploidentical donor was performed in this case. One patient treated with ponatinib and one patient receiving dasatinib maintenance

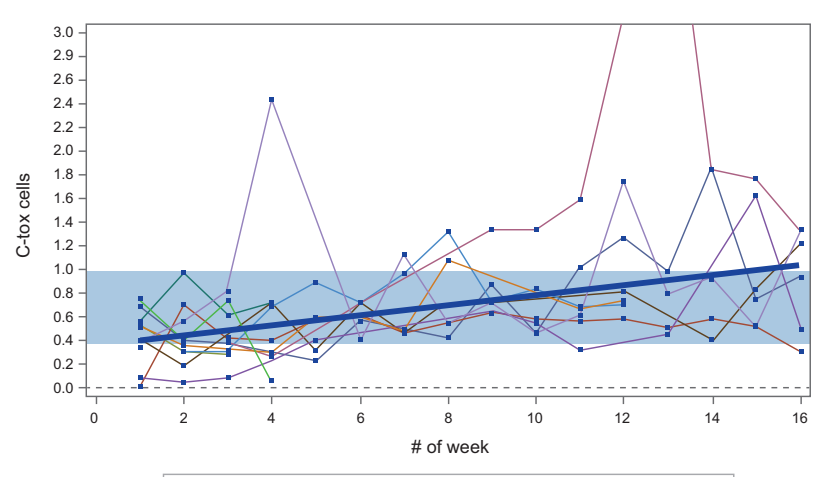

B

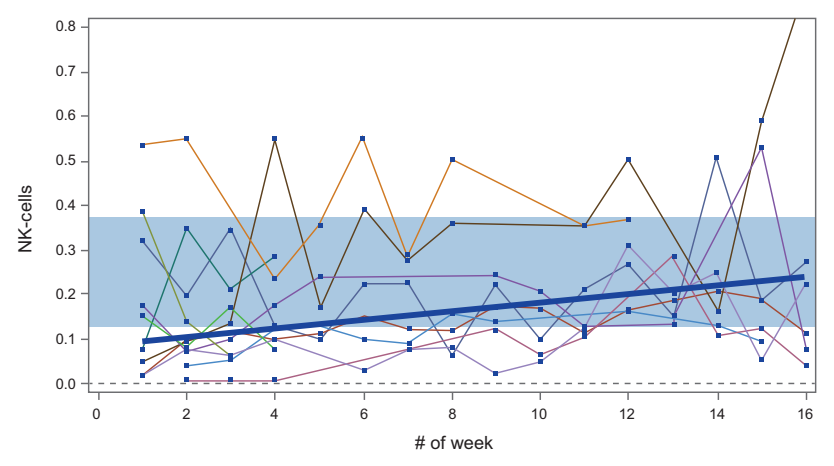

D

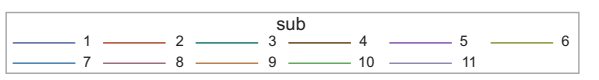

Figure 2. Weekly incremental trends for T-helper cells (A), T cytotoxic cells (B), T-regulatory cells (C), natural killer cells (D), and double-negative cells (E) during blinatumomab + TKI treatment. 16 samples were taken into analyses during 4 cycles of blinatumomab, 4 weekly sampling points for each cycle. Blue band indicates normal ranges for appropriate cell subpopulations. Abscissa, sampling terms, weeks. Ordinate, absolute cell counts in peripheral blood ${ }^{*} 10^{9} / \mathrm{L}$. Bottom lane depicts numbers of individual patients (see Table 1)

after allo-BMT had CNS relapse and CNS lesions that regressed after intrathecal chemotherapy and cranial irradiation. One patient in MolCR died from septic shock 5 months after allo-BMT.

\section{Discussion}

Each patient in the study received combined treatment with blimatumomab immunotherapy and TKI target therapy. The treatment was well tolerated and complications were rare and curable. Hypogammaglobulinemia was common during blinatumomab treatment reflecting strong mature B-cell depletion on anti CD19 treatment. High rate of hypogammaglobulinemia lead to high rate of CMV infection, that was severe in 1 case. Rapid CR achievement and granulocyte 


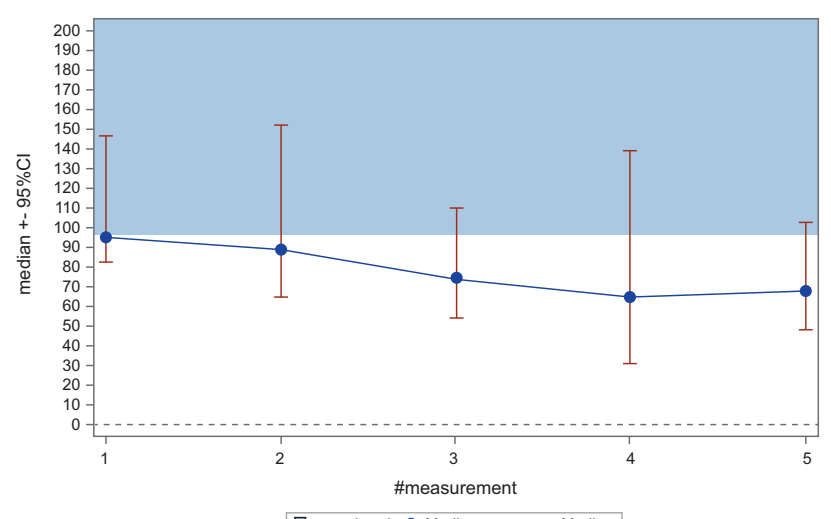

A
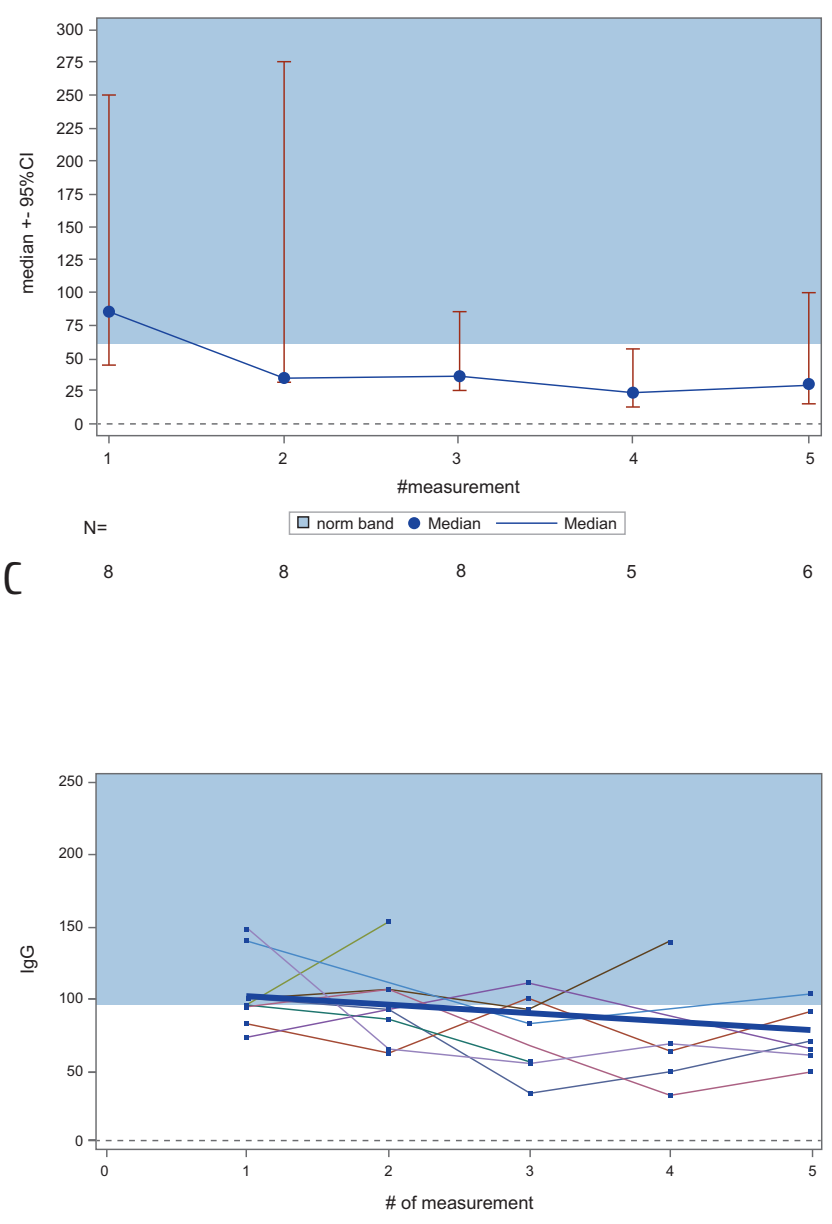

A
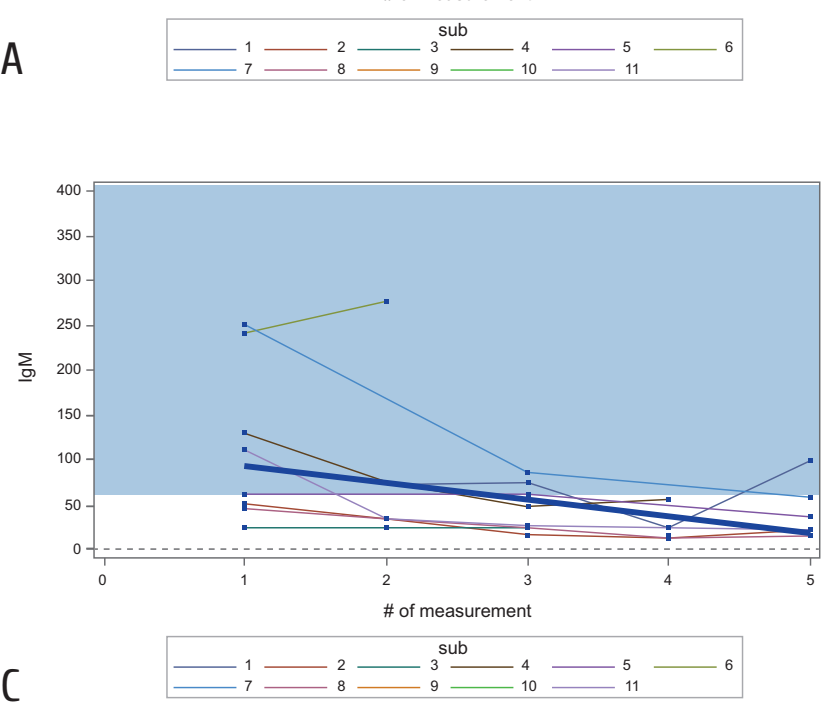

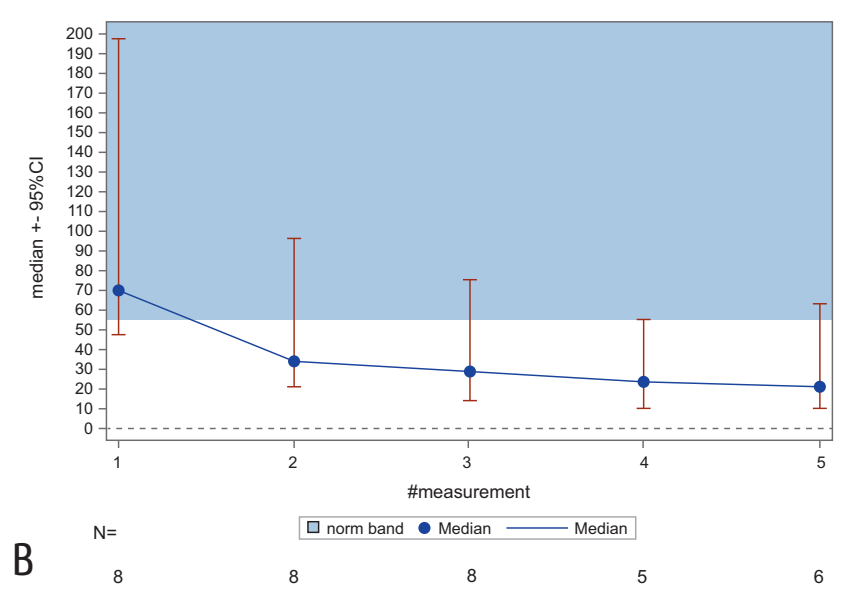

Figure 3. Time kinetics of serum $\lg G(A), \lg A(B)$, and $\lg M$ (C) during Blinotumomab therapy. Median values and 95\%Cl (confidence interval) are shown for each time point. 16 samples were taken into analyses during 4 cycles of blinatumomab, 4 measurement points per 4 cycles of blinatumomab, 1 assay per cycle. Blue band indicates normal ranges for appropriate parameters. Abscissa, numbers of sampling points. Ordinate, IU/ml

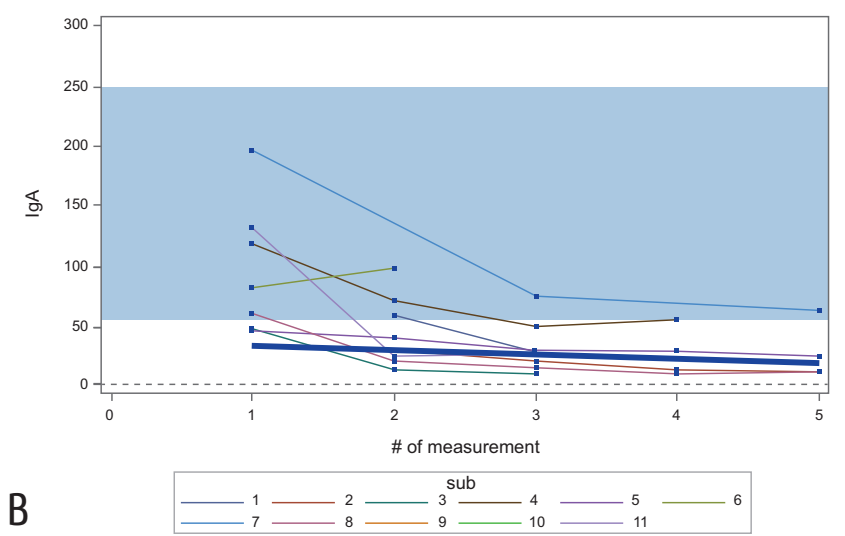

Figure 4. Individual time-dependent dynamics in serum $\lg G(A), \lg A(B)$, and $\lg M(C)$ during therapy with blinotumomab + TKI. One sampling point per each cycle of blinatumomab, 4 measurement points during the treatment period. Blue band indicates normal ranges for appropriate parameters. Abscissa, numbers of sampling points. Ordinate, IU/ml. Bottom: registration numbers of the patients under study (see Table 1) 
recovery permits to treat almost all patients from $2^{\text {nd }}$ to $4^{\text {th }}$ cycles in outpatient settings. Nine molCR and one CyR with only one case of progressive disease permit to recognize this approach as highly effective, with low toxicity profile. Complementary treatment with ATRA in IKZF-deleted pts was also effective strategy though the number of such cases is too small. TKI treatment allows to perform prolonged maintenance, in order to control remaining leukemic populations in some cases. Though the rate of relapses is high, i.e., one half of the pts. However, a cohort of patients had extremely high risk of subsequent relapses and our approach did not exclude this risk entirely. In a single case, replacement of effective TKIs due to toxicity resulted in overt hematological relapse.

Prolonged neutropenia after Allo-BMT resulted in postponing of TKI maintenance and, in all these cases, the dose of eventually administered TKI was lowered by half. Heavily pre-treated patients have higher post-Allo-BMT toxicity, and the maintenance therapy after BMT was not proper. Auto-BMT in Ph-positive patient was not a curative strategy, though in IKZF-deleted patient, AutoBMT with lower toxicity regimen enables us to perform adequate maintenance with two agents, i.e., TKI and ATRA. Recently published results of combined treatment with blinatumomab and TKIs in Ph-positive relapsed ALL had also shown high rates of subsequent remissions and OS values (73\% to $75 \%)$ in a small cohort of patients [11]. Statistical evaluation of changes observed for different lymphoid subpopulations revealed a strong evidence for T-cytotoxic and NK cells recovery in the course of effective combined treatment with blinatumomab and TKI. Duell et al. have demonstrated that lower frequency of T-regulatory cells correlates with higher response to blinatumomab in B-ALL patients [13]. T-regulatory and double-negative cells may potentially inhibit cytotoxic and other effector lymphocytes subpopulations and we observed their fluctuation within lower values of absolute peripheral blood counts in responders to the drug. Rapid and strong B-cell depletion as demonstrated by Zugmaier et al. [14], could explain the dropping immunoglobulin synthesis and prolonged hypogammaglobulinemia in most patients treated with blinatumomab.

\section{Conclusion}

Combined treatment with blinatumomab and TKI has acceptable and curable toxicity and demonstrates high rate of MolCR in high risk R/R ALL pts. The results are promising, with respect of using this treatment as induction and consolidation therapy without standard chemotherapy. IKZF deletions and FLT3-ITD are the new targets for chemo-free combined immunotherapy and TKI in ALL patients.

\section{Acknowledgements}

We thank Amgen for blinatumomab providing. We thank the Russian Acute Leukemia Study Group, National Hematology Society of Russia and also Margarita Anukhina for data management.

\section{References}

1. Perez P, Hoffman RW, Shaw S, Bluestone JA, Segal DM. Specific targeting of cytotoxic T cells by anti-T3 linked to anti-target cell antibody. Nature. 1985; 316:354-356.

2. Baagen A, Van De Griend R, Clark M, Geerars A, Bast B, De Gast B. Killing of human leukaemia/lymphoma B cells by activated cytotoxic $\mathrm{T}$ lymphocytes in the presence of a bispecific monoclonal antibody (mCD3/mCD19). Clin Exp Immunol. 1992; 90: 368-375.

3. Przepiorka D, Ko C-W, Deisseroth A, Yancey CL, Candau-Chacon R, Chiu H-J, Gehrke BJ, Gomez-Broughton C, Kane RC, Kirshner S, Mehrotra N, Ricks TK, Schmiel D, Song P, Zhao P, Zhou Q, Farrell AT, Pazdur R. FDA Approval: Blinatumomab. Clin Cancer Res. 2015; 21(18):4035-4039.

4. Topp MS, Gokbuget N, Stein AS, Zugmaier G, O'Brien S, Bargou RC, Dombret H, Fielding AK, Heffner L, Larson RA, Neumann S, Foà R, Litzow M, Ribera JM, Rambaldi A, Schiller G. Safety and activity of Blinatumomab for adult patients with relapsed or refractory B-precursor acute lymphoblastic leukaemia: A multicentre, single-arm phase 2 study. Lancet Oncol. 2015;16:57-66.

5. Kantarjian H, Stein A, Gokbuget N, Fielding AK, Schuh AC, Ribera J-M, Wei A, Dombret H, Foà R, Bassan R, Arslan Ö, Sanz MA, et al. Blinatumomab versus chemotherapy for advanced acute lymphoblastic leukemia. N Eng J Med. 2017;376:836-847.

6. Martinelli G, Boissel N, Chevallier P, Ottmann O, Gökbuget N, Topp MS, Fielding AK, Rambaldi A, Ritchie EK, Papayannidis C, Sterling LR, Benjamin J, Stein A. Complete hematologic and molecular response in adult patients with relapsed/refractory Philadelphia chromosome-positive B-precursor acute lymphoblastic leukemia following treatment with Blinatumomab: Results from a phase II, singlearm, multicenter study. J Clin Oncol. 2017;35:1795-1802.

7. von Stackelberg A, Locatelli F, Zugmaier G, Handgretinger R, Trippett TM, Rizzari C, Bader P, O'Brien MM, Brethon B, Bhojwani D, Schlegel PG, Borkhardt A, Rheingold SR, Cooper TM, Zwaan CM et al. Phase I/phase II study of Blinatumomab in pediatric patients with relapsed/ refractory acute lymphoblastic leukemia. J Clin Oncol. 2016;34(36):4381-4389.

8. Gokbuget N, Dombret H, Ribera JM, Fielding AK, Advani A, Bassan R, Chia V, Doubek M, Giebel S, Hoelzer D, Ifrah N, Katz A, Kelsh M, Martinelli G, Morgades M, O'Brien $S$ et al. International reference analysis of outcomes in adults with B-precursor Ph-negative relapsed/refractory acute lymphoblastic leukemia. Haematologica. 2016; 101:15241533.

9. Sokolov A, Parovichnikova E, Troitskaya V, Galtseva I, Firsova M, Davidova J, Kapranov N, Savchenko V. Combined Blinatumomab + Dasatinib/Ibrutinib therapy of relapsed acute lymphoblastic leukemia patients - antileukemic effect on the T-helper and T-regulatory cells reduction background. Haematologica. 2016; 101: 354 -355 (E867). 
10. Sokolov AN, Parovichnikova EN, Troitskaya VV, Kuzmina LA, Galtseva IV, Kulikov SM, Bondarenko SN, Davidova JO, Kapranov NM, Lukyanova IA, Lobanova TI, Usikova EI, Zarubina KI, Savchenko VG. Blinatumomab + tyrosine kinase inhibitors with no chemotherapy in BCR-ABL-positive or IKZF1-deleted or FLT3-ITD-positive relapsed/refractory acute lymphoblastic leukemia patients: high molecular remission rate and toxicity profile. Blood. 2017;130:3884.

11. Assi R, Kantarjian H, Short NJ, Daver N, Takahashi K, Garcia-Manero G, DiNardo C, Burger J, Cortes J, Jain N, Wierda W, Chamoun S, Konopleva M, Jabbour E. Safety and efficacy of blinatumomab in combination with a tyrosine kinase inhibitor for the treatment of relapsed Philadelphia chromosome-positive leukemia. Clin Lymphoma Myeloma Leuk. 2017;17(12):897-901.

12. Churchman ML, Low J, Qu C, Paietta EM, Kasper LH, Chang Y, Payne-Turner D, Althoff MJ, Song G, Chen SC, Ma J, Rusch M, McGoldrick D, Edmonson M, Gupta P, Wang YD et al. Efficacy of retinoids in IKZF1-mutated BCR-ABL1 acute lymphoblastic leukemia. Cancer Cell. 2015;28(3): 343-356.

13. Duell J, Dittrich M, Bedke T, Mueller T, Eisele F, Rosenwald A, Rasche L, Hartmann E, Dandekar T, Einsele H, Topp MS. Frequency of regulatory T cells determines the outcome of the T-cell-engaging antibody blinatumomab in patients with B-precursor ALL. Leukemia. (2017);31, 2181-2190.

14. Zugmaier G, Gokbuget N, Klinger M, Viardot A, Stelljes M, Neumann S, Horst H-A, Marks R, Faul C, Diedrich H, Reichle A, Brüggemann M, Holland C, Schmidt M, Einsele H, Bargou RC, Topp MS. Long-term survival and T-cell kinetics in relapsed/refractory ALL patients who achieved MRD response after blinatumomab treatment. Blood. 2015;126(24):2578-2584. 


\title{
BCR/ABL, делеции IKZF и FLT3-ITD как мишени для лечения рецидивов и рефрактерных форм острых В-лимфобластных лейкозов: блинатумомаб в соче- тании с ингибиторами тирозинкиназ и ATRA
}

\author{
Андрей Н. Соколов ${ }^{1}$, Елена Н. Паровичникова ${ }^{1}$, Вера В. Троицкая ${ }^{1}$, Лариса А. Кузьмина ${ }^{1}$, Ирина В. Гальцева ${ }^{1}$, \\ Сергей М. Куликов ${ }^{1}$, Сергей Н. Бондаренко ${ }^{2}$, Ирина А. Лукьянова ${ }^{1}$, Татьяна И. Лобанова ${ }^{1}$, Екатерина И. Усикова ${ }^{1}$, \\ Ксения И. Зарубина ${ }^{1}$, Ольга А. Гаврилина ${ }^{1}$, Юлия О. Давыдова ${ }^{1}$, Николай М. Капранов ${ }^{1}$, Валерий Г. Савченко $^{1}$ \\ ${ }^{1}$ Федеральное государственное бюджетное учреждение научный медицинский исследовательский центр гематологии \\ Минздрава России, Москва, Россия \\ ${ }^{2}$ НИИ детской онкологии, гематологии и трансплантологии им. Р. М. Горбачевой, Первый Санкт-Петербургский \\ государственный медицинский университет им. И. П. Павлова, Санкт-Петербург, Россия
}

\section{Резюме}

Биспецифическое моноклональное антитело блинатумомаб против антигена CD19 используется для лечения острого лимфобластного лейкоза (ОЛЛ). Несколько дополнительных молекулярных мишеней могут быть использованы для комбинированного лечения без обычной химиотерапии, а именно ингибиторы тирозинкиназ, в т.ч. BCR-ABL, FLT3 и делеции IKZF1. Целью данного исследования было определение токсичности и клинической эффективности комбинированного лечения блинатумомабом и несколькими ингибиторами тирозинкиназы.

\section{Пациенты и методы}

С октября 2015 по октябрь 2018 г. нами пролечены 11 пациентов с рецидивируюшим/рефрактерным течением ОЛЛ. Терапия блинатумомабом состояла из 4-5 циклов с 2-недельными интервалами (28 мкг/ день посредством постоянной инфузии в течение 28 дней, при дозе 9 мкг/день в течении 1-й недели 1-го цикла). Семь BCR-ABL-позитивных больных и 2 пациента с делецией IKZF1 получали исходно дазатиниб (140 мг/день), один пациент с FLT3-ITD сорафениб (800 мг/день). Один BCR-ABL-позитивный больной с мутацией T315I получал понатиниб (45 мг/день). Пациентам с делециями IKZF1 назначалась ATRA (45 мг/м²/день в течение 4 недель) на 1-м цикле блинатумомаба и в первые 2 недели последующих циклов лечения антителом.

\section{Результаты}

У пациентов, отвечающих на лечение блинатумомабом, отмечалось статистически достоверное повышение абсолютного количества Т-хелперных лимфоцитов ( $\mathrm{p}=0.0034)$, Т-цитотоксических клеток $(\mathrm{p}<0.0001)$ и субпопуляций естественных киллеров $(\mathrm{p}=0.0006)$ в периферической крови на протяжении всего периода лечения. Т-регуляторные и дубль-негативные Т-клетки - потенциальные ингибиторы Т-клеточного ответа на блинатумомаб оставались в пределах нижних значений нормы. Гипогаммаглобулинемия наблюдалась у 8 из 11 пациентов. Полная ремиссия (ПР) была получена у 10 больных после 1-го цикла блинатумомаба, прогрессия заболевания - в одном случае. Из 10 пациентов, в 9 случаях достигнута полная молекулярная ремиссия (ПМР) и в одном - полная цитогенетическая ремиссия. Выполнены девять аллогенных трансплантаций гемопоэтических стволовых клеток (ТГСК) и одна аутологичная ТГСК в 10 случаях ПР. Выявлены три рецидива в ЦНС после алло-ТГСК и один молекулярный рецидив после ауто-ТГСК. Один пациент скончался от септического шока после алло-ТГСК.

\section{Выводы}

Блинатомомаб в коимбинации с ингибиторами тирозинкиназ имеет высокий терапевтический потенциал для индукции ремиссии в определенных случаях ОЛЛ без применения обычной химиотерапии. Высокая частота потенциальных рецидивов в ЦНС может быть снижена за счет более интенсивной интратекальной профилактики.

\section{Ключевые слова}

Острый лимфобластный лейкоз, блинатумомаб, ингибиторы тирозинкиназ. 